\title{
New records of pleasing lacewings (Neuroptera, Dilaridae) from São Paulo state, Brazil
}

\author{
Rogéria I. R. Lara, Nelson W. Perioto
}

Agência Paulista de Tecnologia dos Agronegócios (APTA), APTA Centro Leste, Av. Bandeirantes 2419, 14030-670, Ribeirão Preto, SP, Brazil. Corresponding author: Rogéria I. R. Lara, rirlara@yahoo.com.br

\begin{abstract}
This note extends the geographic range of Nallachius adamsi Penny, 1981, N. dicolor Adams, 1970 and N. phantomellus Adams, 1970 to São Paulo state, Brazil, based on the examination of specimens obtained in an area of riparian forest ( $21^{\circ} 36^{\prime} 47^{\prime \prime}$ S, $047^{\circ} 49^{\prime} 04^{\prime \prime}$ W, ca $532 \mathrm{~m}$ above sea level) at the Estação Ecológica de Jataí, in the municipality of Luís Antônio.
\end{abstract}

Key words

Light trap; Nallachius adamsi; Nallachius dicolor; Nallachius phantomellus; range extensions.

Academic editor: Tiago Krolow | Received 27 May 2017 | Accepted 1 August 2017 | Published 1 December 2017

Citation: Lara RIR, Perioto NW (2017) New records of pleasing lacewings (Neuroptera, Dilaridae) from São Paulo state, Brazil. Check List 13 (6): 857-862. https://doi.org/10.15560/13.6.857

\section{Introduction}

The Dilaridae (Neuroptera) comprise 2 extinct and 4 extant genera with near 100 species distributed in 3 subfamilies, Berothellinae, Dilarinae and Nallachinae (Aspöck et al. 2015, Zhang et al. 2016, Liu et al. 2017). Due in part to their rarity, the biology of this family is poorly documented (Penny 1981, Bowles et al. 2015, Liu et al. 2017), but the larvae are known live in decayed wood and under barks of dead trees (MacLeod and Spiegler 1961, Penny 1981, Oswald 1998).

The Dilaridae have a disjunct distribution, with occurrence records in North and South America, Europe, Asia and Africa, but they are absent in the Australian region (Oswald 1998, Liu et al. 2017). Of the Nallachinae, Nallachius Navás, 1909 occurs in the Nearctic and Neotropical regions while Neonallachius Nakahara, 1963 is an African and Asian genus (Liu et al. 2017).

The genus Nallachius comprises 20 described spe- cies, of which 10 are known from 12 states of Brazil (Oswald 1998, Monserrat 2005, Machado and Rafael 2010, Martins and Araújo 2016, Liu et al. 2017). Only N. limai Adams, 1970 is recorded from São Paulo state, Brazil (Martins and Amorim 2015). Herein, we reported the first records of Nallachius adamsi Penny, 1981, N. dicolor Adams, 1970, and N. phantomellus Adams, 1970 from São Paulo state.

Little is known about their prey, but there are reports of Nallachius larvae feeding upon larvae of Cucujus clavipes Fabricius, 1775 (Coleoptera, Curculionidae), Elaphidion sp. (Coleoptera, Cerambycidae), and Camponotus castaneus (Latreille, 1802) (Hymenoptera, Formicidae) (MacLeod and Spiegler 1961, Kuhar 1995).

\section{Methods}

The Nallachius specimens were collected with 2 light traps built according to Szentkirályi (2002). These 


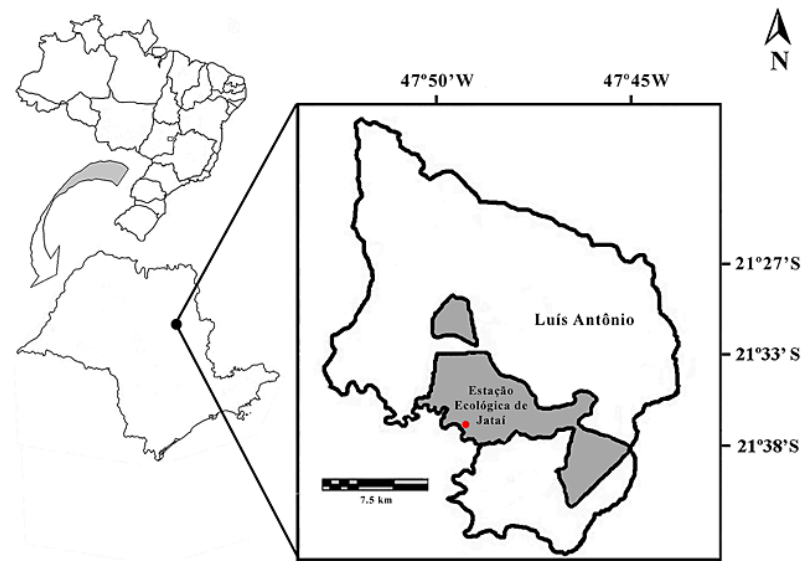

Figure 1. Map of Brazil showing state of São Paulo, in detail the municipality of Luís Antônio and in gray the Estação Ecológica de Jataí. The red spot indicates the collection location of the Nallachius Navás, 1909 (Neuroptera, Dilaridae) species.

traps were operated in an area of riparian vegetation ( $21^{\circ} 36^{\prime} 47^{\prime \prime} \mathrm{S}, 047^{\circ} 49^{\prime} 04^{\prime \prime} \mathrm{W}$, ca $532 \mathrm{~m}$ above sea level) within the Brazilian Savannah domain at the Estação Ecológica de Jataí, in Luís Antônio municipality, São Paulo state, Brazil (Fig. 1). The light traps were separated from each other by $100 \mathrm{~m}$ and fixed in trees inside the forest, ca $2 \mathrm{~m}$ from the ground. The traps were equipped with $250 \mathrm{~W}$ mercury vapor lamps, and their function was controlled by electronic timer coupled to an electromechanical contactor so that the traps remained active on Mondays, Wednesdays, and Fridays, from dusk to dawn, between November 2007 and November 2009. In the traps, a 5\% formalin solution and neutral liquid soap were used as preservative. The captured specimens were sent for identification to the Laboratório de Bioecologia e Taxonomia de Parasitoides e Predadores da APTA Ribeirão Preto, in Ribeirão Preto, São Paulo state, Brazil.

Observations were made under magnification using a stereomicroscope (Leica MZ9.5, Leica Microsystems, Switzerland) and optical microscope (Leica DM500, Leica, China). The color images were obtained with a digital camera (Leica DFC295, Leica, Germany) attached to a stereomicroscope (Leica M205C APO, Leica, Singapore) as well as to a DM500 microscope. Serial images from different layers were combined with Helicon Focus software (v. 5.3) and figures were prepared using Adobe Photoshop software (v. 11.0).

The genitalia were hot-macerated in a $10 \% \mathrm{KOH}$ solution for about $15 \mathrm{~min}$ and subsequently immersed, for $1 \mathrm{~h}$, in a $10 \% \mathrm{C}_{2} \mathrm{H}_{4} \mathrm{O}_{2}$ solution for neutralization. The structures of genitalia were stored in glycerin in glass microvials

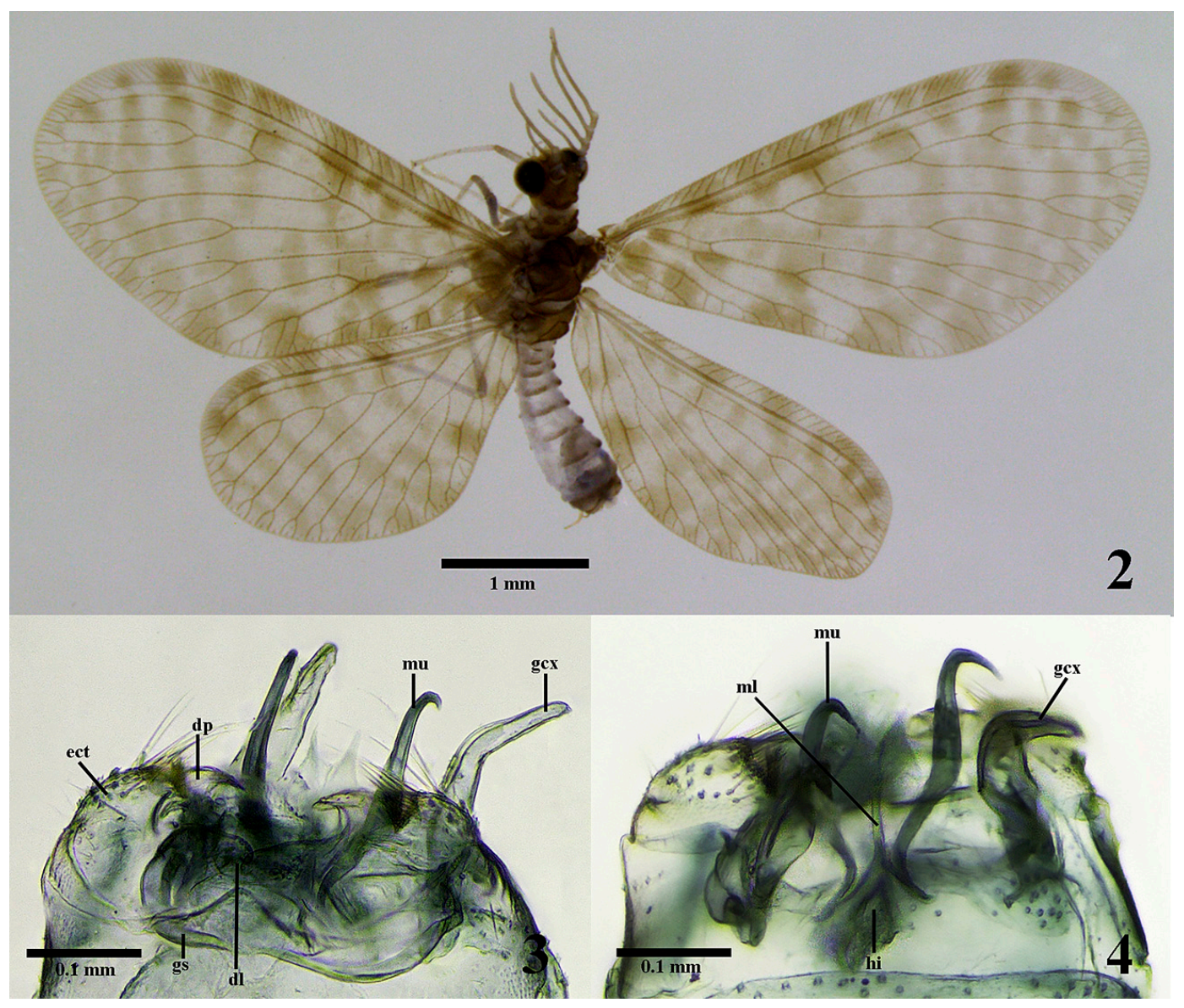

Figures 2-4. Male of Nallachius adamsi Penny, 1981 (Neuroptera, Dilaridae). 2. Habitus, dorsal view. 3. Abdominal apex, dorsal view. 4. Abdominal apex, ventral view. Abbreviations: $\mathrm{dl}=$ dorsal lobe of ectoproct; $\mathrm{dp}=$ digitiform process of ectoproct; ect = ectoproct; $\mathrm{gs}=$ gonarcus; $\mathrm{gcx}=$ gonocoxite; $\mathrm{hi}$ = hypandrium internum; $\mathrm{ml}=$ median lobe; $\mathrm{mu}=$ mediuncus. 


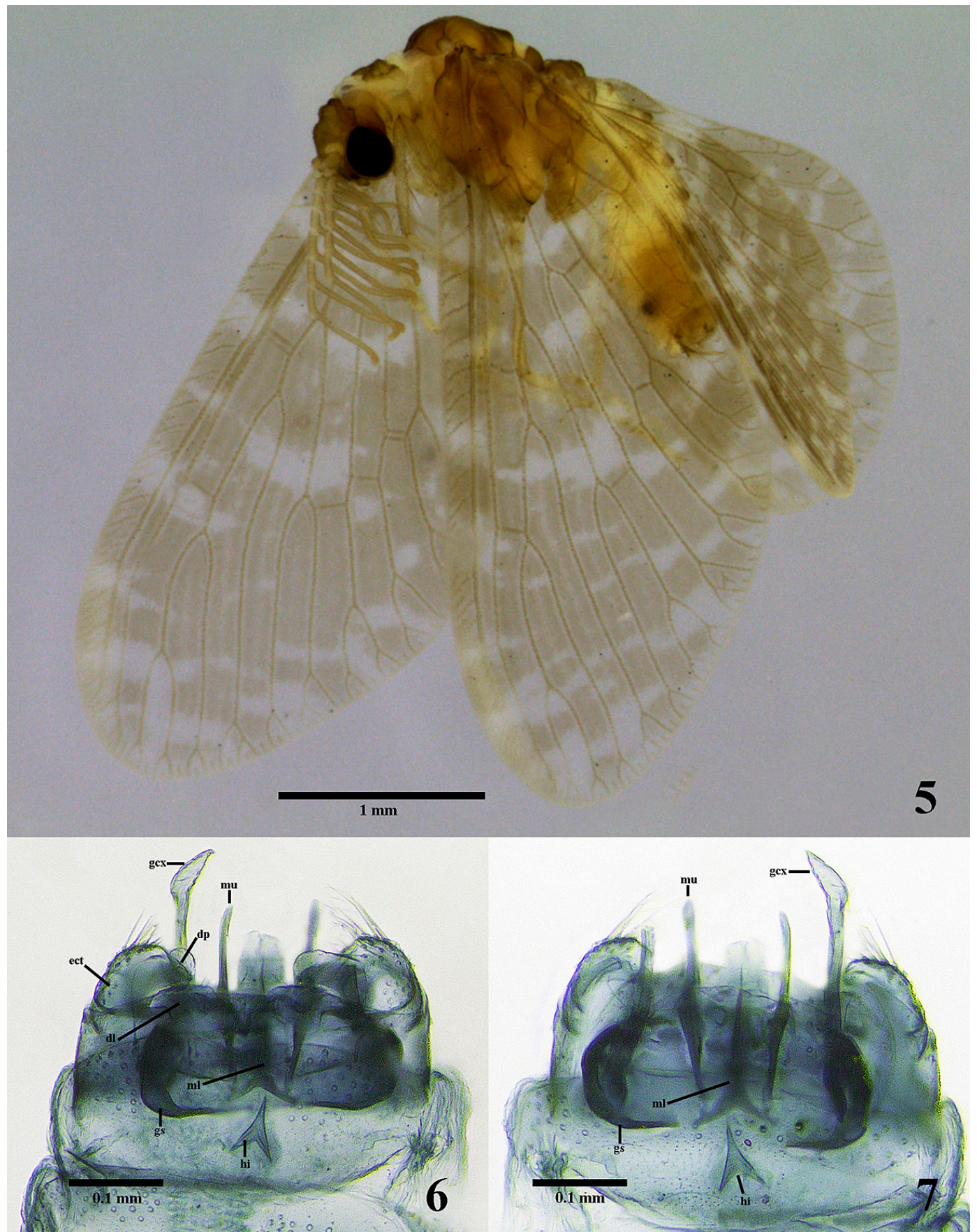

Figures 5-7. Nallachius dicolor Adams, 1970 (Neuroptera, Dilaridae). 5. Habitus, lateral view, 6. Abdominal apex, dorsal view. 7. Abdominal apex, ventral view. Abbreviations: $\mathrm{dl}=$ dorsal lobe of ectoproct; $\mathrm{dp}=$ digitiform process of ectoproct; ect = ectoproct; $\mathrm{gs}=\mathrm{gonarcus} ; \mathrm{gcx}=$ gonocoxite; $\mathrm{hi}=$ hypandrium internum; $\mathrm{ml}=$ median lobe; $\mathrm{mu}=$ mediuncus.

attached in the same pin of the respective specimens.

The voucher specimens, 1 male of $N$. adamsi, 2 males of N. dicolor, and 1 male of $N$. phantomellus (LRRP \#862865) examined in this study were deposited in the Entomological Colletcion of the Laboratório de Sistemática e Bioecologia de Parasitoides e Predadores (LRRP), of the APTA Centro Leste (Ribeirão Preto, SP, Brazil). The collections were done under SISBIO license 16473-1.

The identifications of the Nallachius species were made using the keys of Adams (1970) and Machado and Rafael (2010).

\section{Results}

Nallachius adamsi Penny, 1981

Figures 2-4, 11

Material examined. 1 male, Brasil, SP, Luís Antônio, Estação Ecológica de Jataí, $21^{\circ} 36^{\prime} 47^{\prime \prime} \mathrm{S}, 047^{\circ} 49^{\prime} 04^{\prime \prime} \mathrm{W}$, mata ciliar, ligth trap, 30/IX/2009, RIR Lara and team, legs., LRRP \#862.

The specimen of $N$. adamsi was recognized by the combination of the following morphological characteristics: forewing with RS vein 4 branched, most of costal cross- 

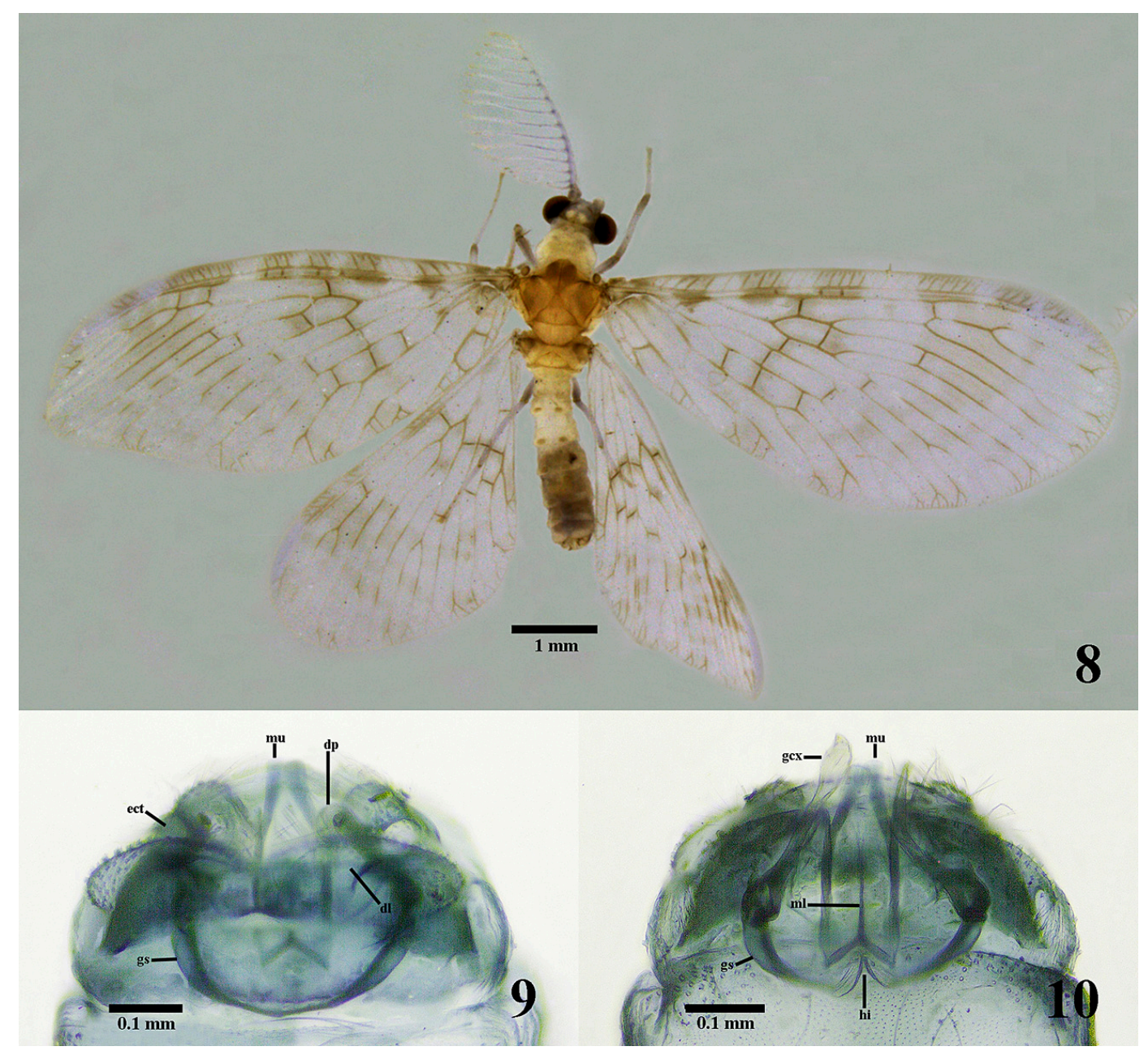

Figures 8-10. Nallachius phantomellus Adams, 1970 (Neuroptera, Dilaridae). 8. Habitus, dorsal view. 9. Abdominal apex, dorsal view. 10. Abdominal apex, ventral view. Abbreviations: $\mathrm{dl}=$ dorsal lobe of ectoproct; $\mathrm{dp}=$ digitiform process of ectoproct; ect = ectoproct; $\mathrm{gs}=$ gonarcus; gcx = gonocoxite; $\mathrm{hi}$ = hypandrium internum; $\mathrm{ml}=$ median lobe; $\mathrm{mu}=$ mediuncus.

veins unforked and, MP2 and CuA veins fused; ectoproct with dorsal lobes long, narrow, with rounded tip and digitiform process well developed, tapering to acute point; gonocoxites long, stoutly pointed with longitudinal groove and subapical notch; mediuncus lobes basally complexly curved, closely approximated and acutely pointed (Penny 1981, Machado and Rafael 2010).

\section{Nallachius dicolor Adams, 1970}

Figures 5-7, 11

Material examined. 1 male, Brasil, SP, Luís Antônio, Estação Ecológica de Jataí, 21³6'47" S, 04749'04" W, mata ciliar, ligth trap, 3/IX/2008, RIR Lara and team, legs., LRRP \#863; 1 male, same data except 11/XI/2009, LRRP \#864.

Specimens of $N$. dicolor were recognized by the pale labrum; forewing with RS vein 4 branched, most of costal crossveins unforked and, MP2 and CuA veins not fused; ectoproct with dorsal lobes approximated on midline, digitiform lobe with stout hook protruding near apex; gonocoxites lancet-shaped, curved outward; mediuncus lobes slender-ligulate apically and, median lobe wide basally, apex simple, only membrane bilobed, projecting beyond lateral processes of mediuncus lobes (Adams 1970, Penny 1981, Machado and Rafael 2010).

Nallachius phantomellus Adams, 1970

Figures 8-11

Material examined. 1 male, Brasil, SP, Luís Antônio, Estação Ecológica de Jataí, 21³6'47" S, 04749'04" W, mata ciliar, ligth trap, 19/VIII/2009, RIR Lara and team, legs., LRRP \#865.

Nallachius phantomellus was recognized by the pale labrum; forewing with RS vein 5 branched, most of costal crossveins unforked and, MP2 and $\mathrm{CuA}$ veins not fused; ectoproct with dorsal lobes approximated on midline, digitiform process cylindrical, bearing a slender hook on medial surface; gonocoxites shorter than in $N$. dicolor, lateral edge angulate so that shape resembles a scimitar, with tip bent dorsally; mediuncus lobes short, spatulate, hardly bent ventrad, lateral projections rounded and median lobe ends at level of these lateral projections (Adams 1970, Machado and Rafael 2010). 


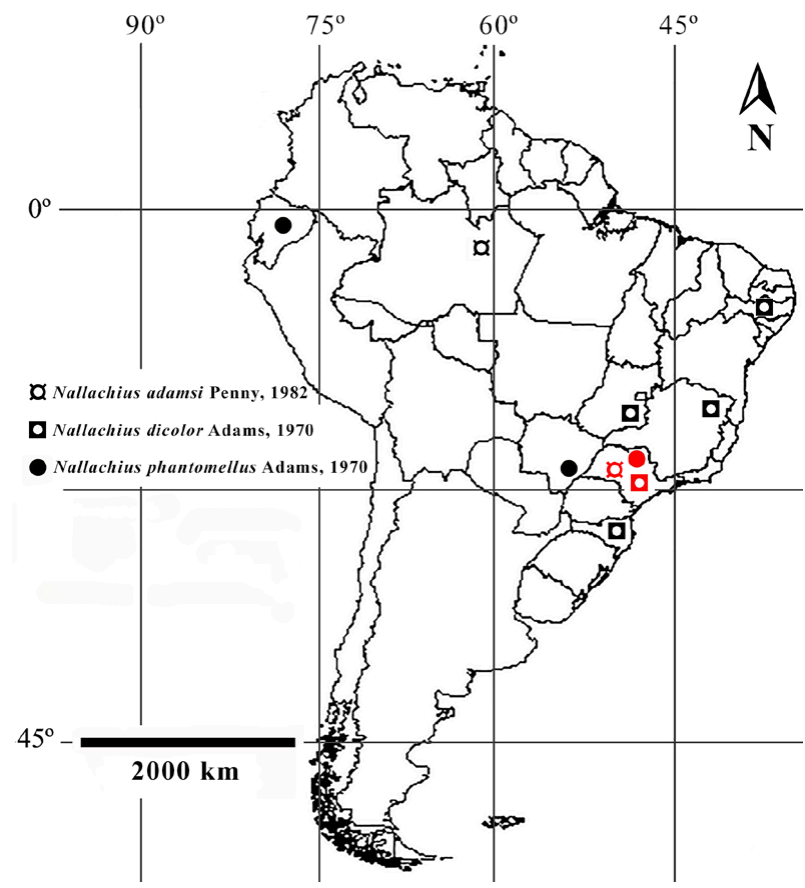

Figure 11. Map of South America showing the previously known records (black) and the new records (red) of Nallachius adamsi Penny, 1981, Nallachius dicolor Adams, 1970 and Nallachius phantomellus Adams, 1970 (Neuroptera, Dilaridae).

\section{Discussion}

In this paper, we document a new distributional record, which extends the geographic range of $N$. adamsi to São Paulo state, about $2400 \mathrm{~km}$ southeast from the type locality at Manaus, Amazonas state, Brazil (Penny 1981; Table 1).

The geographic range of $N$. dicolor is likewise extended to São Paulo state. From the other previously known occurrences, all in Brazil, the new record is about $800 \mathrm{~km}$ northeast from the type locality at Nova Teutonia, Santa Catarina state, about $1800 \mathrm{~km}$ southwest from Jatobá, Pernambuco state, about $900 \mathrm{~km}$ southwest from Berizal, Minas Gerais state, and about $400 \mathrm{~km}$ southeast from Caldas Novas, Goiás state (Adams 1970, Penny 1981, Machado and Rafael 2010, Martins and Araújo 2016; Table 1).

Nallachius phantomellus was known only from the type locality at the Rio Caragualá (probably a misinterpretation of Rio Caraguatá, Bataguassu municipality), Mato Grosso do Sul state, and Orelleana province, Ecuador (Adams 1970, Bowles et al. 2015). We extend to São
Paulo state the geographical range of this species with our new record, which is about $400 \mathrm{~km}$ southeast from the type locality and $4000 \mathrm{~km}$ southeast from Orelleana province (Table 1).

The emergence of the Dilaridae seems to be during the summer, and in the southern hemisphere, the all records were made between October and January except for one each in September and March (Adams 1970; Table 1).

During our 2 years of sampling in the study area only 4 specimens of the 3 species were collected with light traps. Although we sampled at the same time with 2 Malaise traps and collected other families of neuropterans, no Dilaridae were collected. This corroborates the statements of Oswald (1998) and Monserrat (2014) that Dilaridae are typically nocturnal, rarely seen in the field, and thus underrepresented in collections.

This note reveals the incipient nature of the knowledge about the Dilaridae and demonstrates the need of further collection effort to get a better representation of this family in Brazil.

\section{Acknowledgements}

We thank to the Instituto Nacional de Ciência e Tecnologia dos Hymenoptera Parasitoides (INCT/Hympar-CNPq/ Fapesp/Capes) for the financial support.

\section{Authors' Contributions}

RIRL collected the examined exemplars and identified the specimens. Both NWP and RIRL wrote the text.

\section{References}

Adams PA (1970) A review of the New World Dilaridae. Postilla 148: $1-30$.

Aspöck U, Liu X, Aspöck H (2015) The Dilaridae of the Balkan Peninsula and of Anatolia (Insecta, Neuropterida, Neuroptera). Deutsche entomologische Zeitschrift 62: 123-135.

Bowles DE, Contreras-Ramos A, Sarmiento-Cordero MA, Ferro ML (2015) New distributional records for pleasing lacewings (Neuroptera: Dilaridae, Nallachius spp.) in the Americas. Insecta Mundi 0406: 1-10.

Fabricius JC (1775) Systema entomologiae, sistens insectorum classes, ordines, genera, species adiectis synonymis, locis, descriptionibus, observationibus. Korte, Flensburg/Leipzig, 832 pp.

Kuhar TP (1995) A pleasing lacewing, Nallachius americanus (McLachlan), from southwestern Virginia (Neuroptera: Dilaridae). Banister 5: 32-33.

Latreille PA (1802) Histoire naturelle générale et particulière des crustacés et des insectes. Tome 3. Familles naturelles des genres. F.

Table 1. Species of Nallachius Navás, 1909 (Neuroptera, Dilaridae) obtained at the Estação Ecológica de Jataí, in Luís Antônio, São Paulo state, Brazil and known geographic distribution in the Americas and months of collection.

\begin{tabular}{|c|c|c|c|c|}
\hline Nallachius species & Type locality & Distribution & Months of collection & References \\
\hline N. adamsi Penny, 1981 & Brazil, AM, Reserva Duke & Brazil (AM, SP*) & May, July, Sept.* , Dec. & $\begin{array}{l}\text { Penny } 1981, \text { Machado and Rafael 2010, } \\
\text { this study }\end{array}$ \\
\hline N. dicolor Adams, 1970 & Brazil, SC, Nova Teutônia & $\begin{array}{l}\text { Brazil (PE, GO, MG, SP*, } \\
\mathrm{SC})\end{array}$ & $\begin{array}{l}\text { March, Sept.* to Jan., } \\
\text { Nov.* }\end{array}$ & $\begin{array}{l}\text { Adams 1970, Machado and Rafael } 2010, \\
\text { Martins and Araújo 2016, this study }\end{array}$ \\
\hline N. phantomellus Adams, 1970 & Brazil, MS, Rio Caraguatá & Ecuador; Brazil (MS, SP*) & March, July, Aug.* & Adams 1970, Bowles et al. 2015, this study \\
\hline
\end{tabular}

* New records; $\mathrm{AM}=$ Amazonas, GO = Goiás, MG = Minas Gerais, MS = Mato Grosso do Sul, PE = Pernambuco; SC = Santa Catarina, SP = São Paulo. 
Dufart, Paris, 467 pp.

Liu X, Aspöck H, Winterton SL, Zhang W, Aspöck U (2017) Phylogeny of pleasing lacewings (Neuroptera: Dilaridae) with a revised generic classification and description of a new subfamily. Systematic Entomology 42: 448-471. https://doi.org/10.1111/syen.12225

Machado RJS, Rafael JA (2010) Two new species of Dilaridae (Insecta: Neuroptera) with additional notes on Brazilian species. Zootaxa 2421: 61-68. https://doi.org/10.5281/zenodo.194478

MacLeod EG, Spiegler PE (1961) Notes on the larval habitat and developmental peculiarities of Nallachius americanus (MacLachlan) (Neuroptera: Dilaridae). Proceedings of Entomological Society of Washington 63: 281-286.

Martins CC, Amorim DS (2015) First record of pleasing (Neuroptera: Dilaridae) in São Paulo state, Brazil. Check List 11(1): 1538 https://doi.org/10.15560/11.1.1538

Martins CC, Araújo AP (2016) First record of Dilaridae (Neuroptera) in the state of Pernambuco, Brazil. Check List 12(3): 1889. https://doi. org/10.15560/12.3.1889

Monserrat VJ (2005) Nuevos datos sobre algunas pequeñas familias de neurópteros (Insecta: Neuroptera: Nevrorthidae, Osmylidae, Sisyri- dae, Dilaridae). Heteropterus: Revista de Entomología 5: 1-26.

Monserrat VJ (2014) Los diláridos de la península Ibérica (Insecta: Neuropterida: Neuroptera: Dilaridae). Heteropterus: Revista de Entomología 14: 187-214.

Nakahara W (1963) A remarkable new dilarid from India (Neuroptera). Kontyu 31: 77-78.

Navás L (1909) Monografía de la familia de los Diláridos (Ins. Neur.) Memorias de la Real Academia de Ciencias y Artes de Barcelona 7: 619-671.

Oswald JD (1998) Annotated catalogue of the Dilaridae (Insecta: Neuroptera) of the world. Tijdschrift voor Entomologie 141: 115-128.

Penny ND (1981) Neuroptera of the Amazon Basin. Part 2. Dilaridae. Acta Amazonica 11: 383-390.

Szentkirályi F (2002) Fifty-year-long insect survey in Hungary: T Jermy's contributions to light-trapping. Acta Zoologica Academiae Scientiarum Hungaricae 48(Suppl. 1): 85-105.

Zhang W, Liu X, Winterton SL, Aspöck H, Aspöck U (2016) A review of the pleasing lacewing genus Dilar Rambur (Neuroptera, Dilaridae) from Southeast Asia. Zootaxa 4105: 124-144. https://doi. org/10.11646/zootaxa.4105.2.2 